Jurnal Akuntansi \& Perpajakan, Volume 1, No. 2, Januari 2020

\title{
PENGARUH KESADARAN WAJIB PAJAK DAN PENERAPAN SISTEM SAMSAT DRIVE THRU TERHADAP KEPATUHAN WAJIB PAJAK
}

\author{
Tongam Sinambela ${ }^{1}$ \\ Anis Setia Putri² \\ Fakultas Ekonomi Universitas Mpu Tantular
}

\begin{abstract}
This study aims to analyze the effect of taxpayer awareness variables and Drive Thru Samsat System on the level of taxpayer compliance. The population in this study is Taxpayers in West Jakarta Samsat Office. The number of samples in this study were 100 respondents. Data collection techniques used in this study are using questionnaires. Then the data is processed using Microsoft Excel and Statistical Package the Social Science (SPSS) version 22 programs. The results showed that the awareness of taxpayers and the Samsat Drive Thru system had a positive and significant effect on taxpayer compliance using either $\mathrm{t}$ test or $\mathrm{F}$ test. Adjusted R Square figures of 0.472 showed that $47.2 \%$ of taxpayer compliance was influenced by the awareness of taxpayers and Drive Thru Samsat system and $52.8 \%$ are influenced by other factors beyond this research variable.
\end{abstract}

Keywords: Taxpayer Awareness, Drive Thru Samsat System, and Taxpayer Compliance

\begin{abstract}
ABSTRAK
Penelitian ini bertujuan untuk menganalisis pengaruh variabel kesadaran wajib pajak dan Sistem Drive Thru Samsat terhadap tingkat kepatuhan wajib pajak. Populasi dalam penelitian ini adalah Wajib Pajak di Kantor Samsat Jakarta Barat. Jumlah sampel dalam penelitian ini adalah 100 responden. Teknik pengumpulan data yang digunakan dalam penelitian ini adalah menggunakan kuesioner. Kemudian data diproses menggunakan program Microsoft Excel dan Statistik Paket Ilmu Sosial (SPSS) versi 22. Hasil penelitian menunjukkan bahwa kesadaran wajib pajak dan sistem Samsat Drive Thru memiliki pengaruh positif dan signifikan terhadap kepatuhan wajib pajak menggunakan uji t atau uji F. Angka Adjusted R Square sebesar 0,472 menunjukkan bahwa 47,2\% kepatuhan wajib pajak dipengaruhi oleh kesadaran wajib pajak dan sistem Drive Thru Samsat dan $52,8 \%$ dipengaruhi oleh faktor lain di luar variabel penelitian ini.
\end{abstract}

Kata kunci: Kesadaran Wajib Pajak, Sistem Drive Thru Samsat, dan Kepatuhan Wajib Pajak

Korespondensi: Tongam Sinambela, SE, MM, M.Ak,. Fakultas Ekonomi Universitas Mpu Tantular. Cipinang Besar No. 2 Jakarta Timur, 13410. tongamsinambela@mputantular.ac.id 
Jurnal Akuntansi \& Perpajakan, Volume 1, No. 2, Januari 2020

\section{PENDAHULUAN}

Percepatan pertumbuhan jumlah adalah salah satu penyebabnya. Berikut kendaraan bermotor yang sangat signifikan merupakan data pertumbuhan jumlah di Provinsi DKI Jakarta tidak disertai dengan kendaraan bermotor menurut jenisnya di peningkatan penerimaan pajak kendaraan Jakarta Barat, sebagai berikut: bermotor. Rendahnya kesadaran wajib pajak

Tabel 1. Data Jumlah Kendaraan Bermotor per jenis kendaraan bermotor Tahun 2013-2017

\begin{tabular}{|c|l|r|r|r|r|r|}
\hline No Jenis KBm & \multicolumn{1}{|c|}{$\mathbf{2 0 1 3}$} & $\mathbf{2 0 1 4}$ & \multicolumn{1}{c|}{$\mathbf{2 0 1 5}$} & \multicolumn{1}{c|}{$\mathbf{2 0 1 6}$} & \multicolumn{1}{c|}{$\mathbf{2 0 1 7}$} \\
\hline 1 & Sedan dan sejenisnya & 66.163 & 66.513 & 65.257 & 63.087 & 60.480 \\
\hline 2 & Jeep segala merk & 38.483 & 40.899 & 42.173 & 43.955 & 44.510 \\
\hline 3 & Minibus, microbus & 245.300 & 264.203 & 279.494 & 298.646 & 300.104 \\
\hline 4 & Pick up, Light truck, Truck dan sejenisnya & 47.559 & 49.173 & 49.345 & 48.065 & 45.282 \\
\hline 5 & BT wagon,Wagon, Box, Delivery van & 35.641 & 37.276 & 37.329 & 36.173 & 34.602 \\
\hline 6 & Dum truck, truck tangki dan sejenisnya & 8.593 & 8.933 & 9.070 & 9.088 & 8.763 \\
\hline 7 & Otoplet/opelet, microlet & 2.762 & 2.756 & 2.778 & 2.769 & 2.753 \\
\hline 8 & Kendaraan bermotor roda tiga & 3.573 & 3.615 & 3.686 & 4.952 & 4.390 \\
\hline 9 & Sepeda motor & 1.336 .219 & 1.448 .263 & 1.535 .097 & 1.612 .235 & 1.659757 \\
\hline 10 & Alat-alat berat & 9.694 & 10.672 & 11.054 & 10.881 & 11.123 \\
\hline & Total & $\mathbf{1 . 7 9 3 . 9 8 7}$ & $\mathbf{1 . 9 3 2 . 3 0 3}$ & $\mathbf{2 . 0 3 5 . 2 8 3}$ & $\mathbf{2 . 1 2 9 . 8 5 1}$ & $\mathbf{2 . 1 7 1 . 7 6 4}$ \\
\hline
\end{tabular}

Sumber : Badan Pelayanan Pajak dan Retribusi Daerah Provinsi DKI Jakarta

Dari tabel di atas terlihat bahwa pertumbuhan jumlah kendaraan bermotor setiap tahun mengalami peningkatan untuk keseluruhannya, tetapi tidak untuk masingmasing jenis kendaraan Bermotor. Ada beberapa jenis kendaraan yang mengalami fluktuasi setiap tahunnya, yang mengalami kenaikan rutin setiap tahun ada di jenis kendaraan bermotor di antaranya jeep segala merk, minibus dan microbus, kendaraan bermotor roda tiga, sepeda motor, dan alatalat berat. Namun dari kenaikan tersebut tidak seluruh Wajib Pajak yang terdaftar memiliki kepatuhan membayar pajak. Berikut adalah rekap penerimaan Pajak Kendaraan Bermotor dari Rencana dan Realisasi dan Jumlah dari keseluruhan Wajib Pajak yang terdaftar dari keseluruhan jenis kendaraan bermotor.

Tabel 2. Jumlah Penerimaan PKB dan Jumlah Kendaraan Yang Membayar Pajak Tahun 2013-2017

\begin{tabular}{|c|r|r|r|}
\hline Tahun & \multicolumn{1}{|c|}{ Target } & Realisasi & KBM \\
\hline 2013 & 922.940 .230 .828 & 824.822 .562 .596 & 1.176 .164 \\
\hline 2014 & 1.012 .688 .587 .713 & 880.680 .480 .106 & 1.108 .961 \\
\hline
\end{tabular}


Jurnal Akuntansi \& Perpajakan, Volume 1, No. 2, Januari 2020

\begin{tabular}{|l|l|l|r|}
2015 & 1.132 .315 .000 .000 & 1.111 .551 .014 .537 & 1.142 .173 \\
\hline 2016 & 1.278 .135 .000 .000 & 1.366 .691 .543 .355 & 1.270 .058 \\
\hline 2017 & 1.552 .000 .000 .000 & 1.698 .874 .415 .928 & 1.234 .132 \\
\hline \multicolumn{4}{|c}{ Sumber: Kantor Samsat Daan Mogot Jakarta Barat }
\end{tabular}

Pemerintah Daerah menargetkan pendapatan pajak dari sektor Pajak Kendaraan Bermotor. Dari data yang diperoleh adanya penurunan di antara Tahun 2013 sampai 2015 dan memperoleh kenaikan penerimaan dari Tahun 2016 sampai 2017. Namun jumlah kendaraan yang patuh membayar pajak tidak setinggi jumlah kendaraan yang terdaftar. Dari fenomena ini menjelaskan bahwa kepatuhan Wajib Pajak kendaraan bermotor belum maksimal. Untuk itu setiap Samsat di Pemerintah Daerah memiliki berbagai macam inovasi pelayanan salah satunya, sistem layanan Drive Thru di Kantor Samsat. Samsat Drive Thru adalah pelayanan dimana Wajib Pajak tidak perlu turun dari kendaraan cukup melakukan proses pendaftaran dan membayar dari atas kendaraan. Pemilik kendaraan cukup menyiapkan dokumen seperti BPKB, STNK, dan KTP asli tanpa harus repot fotokopi. Setelah itu langsung bergeser ke loket dua untuk pembayaran dan pengambilan dokumen baru.

Berikut adalah data mengenai perkembangan sistem layanan Drive Thru periode 2013 sampai dengan 2017.

Tabel 3. Drive Thru Jakarta Barat

\begin{tabular}{|c|c|c|}
\hline Tahun & Jumlah KBm & $\begin{array}{c}\text { Jumlah PKB pokok dan } \\
\text { denda }\end{array}$ \\
\hline 2013 & 40.268 & 14.849 .931 .400 \\
\hline 2014 & 45.909 & 16.537 .001 .300 \\
\hline 2015 & 47.199 & 21.381 .243 .000 \\
\hline 2016 & 47.237 & 24.886 .700 .200 \\
\hline 2017 & 49.076 & 26.380 .869 .700 \\
\hline
\end{tabular}

Sumber : Badan Pelayanan Pajak dan Retribusi Daerah Provinsi DKI Jakarta

\section{Rumusan Masalah}

1. Bagaimana pengaruh dari implementasi sistem Samsat Drive Thru terhadap kepatuhan Wajib Pajak?

2. Bagaimana pengaruh kesadaran Wajib Pajak terhadap tingkat kepatuhan Wajib Pajak di Kantor Samsat Jakarta Barat?

3. Bagaimana kesadaran Wajib Pajak, dan sistem samsat Drive Thru berpengaruh terhadap tingkat kepatuhan Wajib Pajak di Kantor Samsat Jakarta Barat?

\section{Tujuan Penelitian}

Tujuan penelitian ini adalah untuk mengetahui bagaimana implementasi dari pelayanan sistem samsat Drive Thru terhadap kepatuhan Wajib Pajak, mengetahui seberapa besar tingkat kesadaran wajib pajak berpengaruh pada tingkat kepatuhan Wajib Pajak dan untuk pengaruh kesadaran Wajib Pajak, sistem 
Jurnal Akuntansi \& Perpajakan, Volume 1, No. 2, Januari 2020

samsat Drive Thru terhadap tingkat kepatuhan Wajib Pajak.

\section{TINJAUAN PUSTAKA}

Kepatuhan wajib pajak bisa dipengaruhi oleh beberapa faktor dan dapat dilihat dari banyak perspektif: kecenderungan terhadap instansi publik (Dalam hal ini Direktorat jenderal Pajak), Keadilan yang dirasakan, persepsi keadilan, dan ketegasan Undang-Undang dan sanksi. (Ilhamsyah, dkk, 2016). Teori ini berkeyakinan bahwa tidak ada Wajib Pajak yang bersedia membayar pajak secara sukarela. Secara mendasar penghindaran pajak tergantung dan berbanding terbalik pada kemungkinan terkena sanksi dan ukuran sanksi yang dikenakan, tidak adanya keadilan yang diberikan pemerintah pada wajib pajak tidak patuh. Dengan demikian teori ini semata-mata meletakkan kepatuhan pajak pada pundak Wajib Pajak.

Berdasarkan Undang-Undang Nomor 28 Tahun 2009 pengertian Pajak Kendaraan Bermotor adalah pajak atas kepemilikan dan/atau penguasaan kendaraan bermotor. Sedangkan kendaraan bermotor adalah semua kendaraan beroda beserta gandengannya yang digunakan di semua jenis jalan darat, dan digerakkan oleh peralatan teknik berupa motor atau peralatan lainnya yang berfungsi untuk mengubah suatu sumber daya energi tertentu menjadi tenaga gerak kendaraan bermotor yang bersangkutan, termasuk alat-alat berat dan alat-alat besar yang dalam operasinya menggunakan roda dan motor dan tidak melekat secara permanen serta kendaraan bermotor yang dioperasikan di air.

$$
\frac{\text { Jumlah Wajib Pajak yang membayar pajak }}{\text { Jumlah Wajib Pajak yang terdaftar }} \times 100 \%
$$


Jurnal Akuntansi \& Perpajakan, Volume 1, No. 2, Januari 2020

\section{Kerangka Pemikiran}

samsat Drive Thru terhadap kepatuhan Wajib Pajak dalam membayar Pajak Kendaraan Bermotor (PKB). Kerangka pemikiran penelitian ini disajikan pada

Dalam penelitian ini akan dijelaskan gambar sebagai berikut:

mengenai kesadaran Wajib Pajak, sistem

\section{Gambar 1 \\ Kerangka Pemikiran}

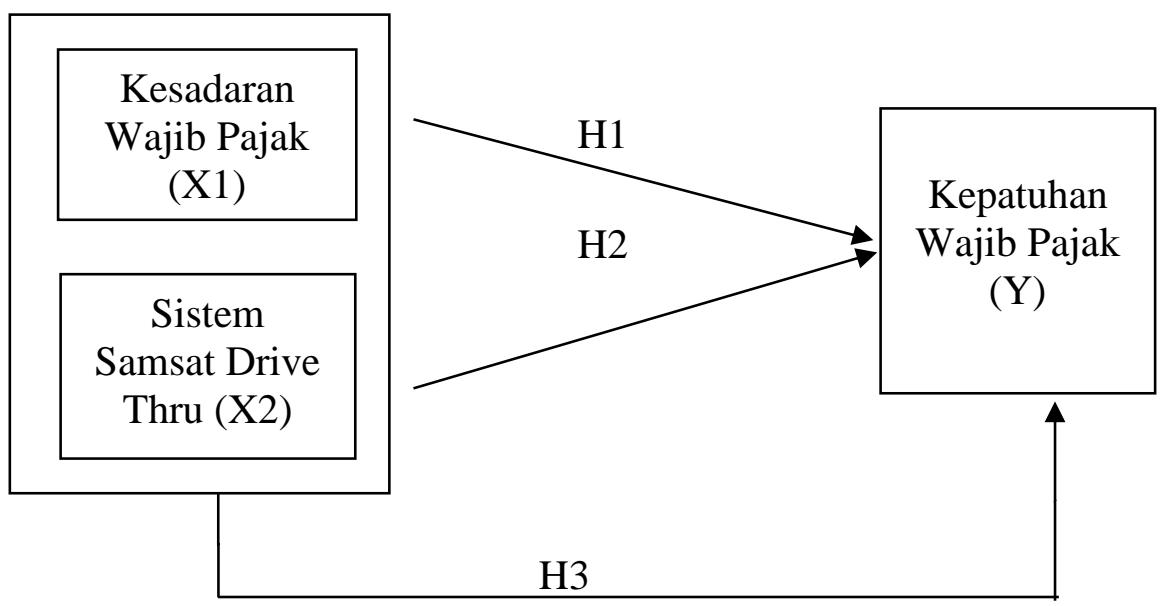

Hipotesis:

H1 : Kesadaran wajib Pajak berpengaruh terhadap kepatuhan Wajib Pajak.

H2 : Sistem Samsat Drive Thru berpengaruh terhadap kepatuhan Wajib Pajak.

\section{METODE}

Metode penelitian pada dasarnya merupakan cara ilmiah untuk mendapatkan data dengan tujuan dan kegunaan tertentu. Cara ilmiah berarti kegiatan penelitian ini didasarkan pada ciri-ciri keilmuan, yaitu rasional, empiris, dan sistematis. Rasional
H3 : Kesadaran Wajib Pajak, dan Sistem Samsat Drive Thru berpengaruh terhadap kepatuhan Wajib Pajak. 
Jurnal Akuntansi \& Perpajakan, Volume 1, No. 2, Januari 2020

cara yang digunakan. Sistematis artinya proses yang digunakan dalam penelitian ini menggunakan langkah-langkah tertentu yang bersifat logis.

\section{Populasi dan Sampel}

Populasi penelitian ini adalah Wajib Pajak yang berada di Kantor Samsat Daan Mogot Jakarta Barat seluruhnya berjumlah 2.171.764. sedangkan sampel adalah sebagian dari jumlah dan karakteristik yang dimiliki oleh populasi. Untuk menentukan jumlah sampel menggunakan metode purposive sampling, yaitu teknik penentuan sampel dengan pertimbangan tetentu.

Penentuan jumlah sampel minimal dalam penelitian ini mengacu pada (Roscoe, 1975; Sinambela, Lijan Poltak 2014:108-109) menyatakan bahwa :

1. Ukuran sampel yang layak dalam penelitian adalah antara 30 sampai dengan 500.

2. Bila sampel dibagi dalam kategori (misalnya : pria-wanita, pegawai negeri-swasta, dan lain-lain) maka jumlah anggota sampel setiap kategori minimal 30.

3. Bila dalam penelitian akan melakukan analisis dengan multivariate (korelasi atau regresi ganda misalnya), maka jumlah anggota sampel minimal 10 kali dari jumlah variabel yang diteliti. Misalnya variabel penelitiannya ada 5 (independen + dependen), maka jumlah anggota anggota sampel $10 \times 5=50$.

4. Untuk penelitian eksperimen yang sederhana, yang menggunakan kelompok eksperiman dan kelompok kontrol, maka jumlah anggota sampel masing-masing antara 10 sampai dengan 20.
Dengan pertimbanga diatas dan keterbatasan tenaga, biaya serta waktu maka sampel yang diambil dalam penelitian ini berjumlah 100 responden Wajib Pajak Kendaraan Bermotor.

\section{Metode Analisis Data dan Pengujian Hipotesis}

Analisis data adalah upaya atau cara untuk mengolah data menjadi informasi sehingga karakteristik data tersebut bisa dipahami dan bermanfaat untuk solusi permasalahan, terutama masalah yang berkaitan dengan penelitian. Analisis dalam penelitian ini menggunakan teknik analisis regresi berganda untuk mengolah dan membahas data yang telah diperoleh untuk menguji hipotesis yang dilakukan. Jenis data yang dilakukan dalam peneitian ini adalah data kuantitatif penelitian dengan memperoleh data yang berbentuk angka.

\section{Uji Validitas}

Uji validitas dilakukan dengan cara menguji korelasi antara skor item dengan skor total masing-masing variabel. Secara statistik, angka korelasi berbagai total yang diperoleh harus dibandingkan dengan angka dalam $r$ product moment. Apabila nilai $r$ dihitung lebih besar atau sama dengan $r$ tabel maka kuesioner tersebut diakatakan valid dan sebaliknya.

\section{Uji Reliabilitas}

Uji reliabilitas berguna untuk menetapkan apakah instrument yang dalam kuesioner dapat digunakan lebih dari satu kali, paling tidak pada responden yang sama. Alat untuk mengukur reliabilitas adalah Koefisien Alpha Cronbach. Apabila koefisien alpha > 0,6 maka dapat dinyatakan bahwa instrumen kuisioner yang digunakan 
Jurnal Akuntansi \& Perpajakan, Volume 1, No. 2, Januari 2020

adalah reliabel. (Hardiningsih dan Yulianawati).

\section{Uji Asumsi Klasik}

Uji asumsi klasik yang digunakan dalam penelitian ini adalah uji normalitas, uji multikolinieritas, dan uji heterokedastisitas.

\section{Analisis Regresi Linier Berganda}

Persamaan ini digunakan untuk mengetahui adanya pengaruh antara variabel independen yaitu kesadaran wajib pajak, pemahaman wajib pajak, dan kualitas pelayanan terhadap variabel dependen yaitu kepatuhan wajib pajak. Metode yang digunakan dalam penelitian ini adalah :

$$
\mathrm{Y}=\mathrm{a}+\mathrm{b} 1 \mathrm{X} 1+\mathrm{b} 2 \mathrm{X} 2+\mathrm{e}
$$

\section{Dimana :}

$\mathrm{Y}=$ Kepatuhan Wajib pajak

$a=$ Konstanta

b1 = Koefisien Regresi dari

Variabel kesadaran wajib pajak

b2 = Koefisien Regresi dari

Variabel sistem samsat Drive

Thru

X1 = Kesadaran Wajib Pajak

$\mathrm{X} 2=$ Sistem Samsat Drive Thru

$\mathrm{E}=$ Error Term, yaitu tingkat kesalahan penduga dalam penelitian

\section{Uji Hipotesis}

Pengujian hipotesis pengaruh variabel independen terhadap dependen dilakukan dengan menggunakan analisis regresi

\section{HASIL DAN PEMBAHASAN}

Samsat merupakan singkatan dari Sistem Administrasi Manunggal satu atap atau dalam Bahasa Inggris disebut "One Roof System" yang dapat diartikan sebagai suatu sistem administrasi yang kegiatannya diselenggarakan dalam satu gedung, dan berganda. Analisis regresi digunakan untuk memprediksi pengaruh lebih dari satu variabel bebas terhadap satu variabel terikat, baik secara parsial maupun simultan.

\section{Uji F (Simultan)}

Uji $\mathrm{F}$ bertujuan untuk mengetahui pengaruh variabel independen terhadap variabel dependen secara simultan (Ilhamsyah,dkk, 2016). Kriteria penerimaan hipotesis $\left(\mathrm{H}_{\mathrm{a}}\right.$ diterima adalah nilai $\mathrm{F}$ hitung $>\mathrm{F}$ tabel atau nilai sig <0.05).

\section{Uji t (Parsial)}

Untuk menguji apakah variabel bebas berpengaruh secara signifikansi terhadap variabel terkait. Tingkat signifikansi yang digunakan adalah 5\%. Jika probability $\mathrm{T}_{\text {hitung }} \mathrm{P}<0,05$ maka $\mathrm{H}_{\mathrm{o}}$ ditolak, sebaliknya juka propability $\mathrm{T}_{\text {hitung }} \mathrm{P}>0.05$ maka Ho diterima. Pengujian dilakukan dengan sig dari $\mathrm{T}$ hitung pada degree of freedom (derajat kebebasan) tertentu dan membandingkan dengan tingkat signifikansi sebesar $a=5 \%$.

\section{Uji koefisien Determinasi}

Koefisien determinasi menunjukkan mengenai besarnya pengaruh variabel independen terhadap variabel dependen. Rumusan koefisien determinasi adalah Adjusted $R^{2} \times 100 \%$. Hasil pengujian dapat dilihat di tabel model summary.

dibentuk guna memperlancar serta mempercepat pelayanan kepentingan masyarakat. Semisal dalam pengurusan dokumen atau pembayaran Pajak Kendaraan Bermotor. 
Jurnal Akuntansi \& Perpajakan, Volume 1, No. 2, Januari 2020

Di Indonesia, Samsat merupakan satu sistem kerjasama secara terpadu antara Dinas Pendapatan Provinsi, Polri, dan PT Jasa Raharja (Persero) dalam pelayanannya untuk penerbitan Surat Tanda Nomor Kendaraan Bermotor dan Tanda Nomor Kendaraan.

Kegiatan tersebut dikaitkan dengan pemasukan uang kas Negara baik melalui Pajak Kendaraan Bermotor (PKB), Bea Balik Nama Kendaraan Bermotor, maupun Sumbangan Wajib Dana Kecelakaan Lalu Lintas Jalan (SWDKLLJ). Pelaksanaan dari kegiatan ini dilaksanakan dalam satu kantor yang biasa disebut dengan "Kantor Bersama Samsat". Dalam hal ini Polri memiliki fungsi penerbitan STNK, Dinas Pendapatan Provinsi menetapkan besarnya Pajak Kendaraan Bermotor (PKB) dan Bea Balik Nama Kendaraan Bermotor (BBN-KB), sedangkan PT Jasa Raharja mengelola Sumbangan Wajib Dana Kecelakaan Lalu Lintas Jalan (SWDKLLJ). Lokasi Kantor Bersama Samsat umumnya berada di lingkungan /kota Satlantas/Ditlantas Polda setempat. Samsat ada di masing-masig provinsi, serta memiliki unit pelayanan disetiap Kabupaten/Kota.

Tabel 4. Data Jumlah Kendaraan Bermotor Per Jenis Kendaraan Bermotor Tahun 2013-2017

\begin{tabular}{|c|l|r|r|r|r|r|}
\hline No & \multicolumn{1}{|c|}{ Jenis KBm } & \multicolumn{1}{c|}{$\mathbf{2 0 1 3}$} & \multicolumn{1}{c|}{$\mathbf{2 0 1 4}$} & \multicolumn{1}{c|}{$\mathbf{2 0 1 5}$} & \multicolumn{1}{|c|}{$\mathbf{2 0 1 6}$} & \multicolumn{1}{c|}{$\mathbf{2 0 1 7}$} \\
\hline 1 & Sedan dan sejenisnya & 66.163 & 66.513 & 65.257 & 63.087 & 60.480 \\
\hline 2 & Jeep segala merk & 38.483 & 40.899 & 42.173 & 43.955 & 44.510 \\
\hline 3 & Minibus, microbus & 245.300 & 264.203 & 279.494 & 298.646 & 300.104 \\
\hline 4 & $\begin{array}{l}\text { Pick up, Light truck, Truck dan } \\
\text { sejenisnya }\end{array}$ & 47.559 & 49.173 & 49.345 & 48.065 & 45.282 \\
\hline 5 & $\begin{array}{l}\text { BT wagon,Wagon, Box, Delivery } \\
\text { van }\end{array}$ & 35.641 & 37.276 & 37.329 & 36.173 & 34.602 \\
\hline 6 & $\begin{array}{l}\text { Dum truck, truck tangki dan } \\
\text { sejenisnya }\end{array}$ & 8.593 & 8.933 & 9.070 & 9.088 & 8.763 \\
\hline 7 & Otoplet/opelet, microlet & 2.762 & 2.756 & 2.778 & 2.769 & 2.753 \\
\hline 8 & Kendaraan bermotor roda tiga & 3.573 & 3.615 & 3.686 & 4.952 & 4.390 \\
\hline 9 & Sepeda motor & 1.336 .219 & 1.448 .263 & 1.535 .097 & 1.612 .235 & 1.659757 \\
\hline 10 & Alat-alat berat & 9.694 & 10.672 & 11.054 & 10.881 & 11.123 \\
\hline \multicolumn{1}{|c}{ Total } & $\mathbf{1 . 7 9 3 . 9 8 7}$ & $\mathbf{1 . 9 3 2 . 3 0 3}$ & $\mathbf{2 . 0 3 5 . 2 8 3}$ & $\mathbf{2 . 1 2 9 . 8 5 1}$ & $\mathbf{2 . 1 7 1 . 7 6 4}$ \\
\hline
\end{tabular}

Sumber : Badan Pelayanan Pajak dan Retribusi Daerah Provinsi DKI Jakarta

Adapun jumlah pembayaran Pajak kendaraan bermotor di Kantor Samsat dari Kendaraan Bermotor Berdasarkan jenis periode 2013-2017, yakni : 
Jurnal Akuntansi \& Perpajakan, Volume 1, No. 2, Januari 2020

Tabel 5. Data Jumlah Pembayaran Pajak Kendaraan Bermotor Berdasarkan Jenis Kendaraan Bermotor Tahun 2013 - 2017

\begin{tabular}{|l|r|r|r|r|r|}
\hline \multicolumn{1}{|c|}{ Jenis KBm } & \multicolumn{1}{c|}{$\mathbf{2 0 1 3}$} & \multicolumn{1}{c|}{$\mathbf{2 0 1 4}$} & \multicolumn{1}{c|}{$\mathbf{2 0 1 5}$} & \multicolumn{1}{c|}{$\mathbf{2 0 1 6}$} \\
\hline Sedan dan sejenisnya & 89.911 .326 .100 & 93.179 .464 .150 & 114.360 .356 .900 & 130.858 .234 .870 & 158.338 .277 .700 \\
\hline Jeep segala merk & 107.667 .598 .300 & 115.832 .268 .300 & 143.100 .119 .000 & 184.404 .736 .450 & 238.918 .000 .850 \\
\hline Minibus, microbus & 350.388 .288 .500 & 381.007 .262 .969 & 506.083 .414 .350 & 648.642 .133 .751 & 819.740 .765 .808 \\
\hline Pick up, Light truck, Truck dan sejenisnya & 43.290 .393 .000 & 46.235 .241 .205 & 50.687 .931 .676 & 52.381 .394 .400 & 53.527 .446 .000 \\
\hline BT wagon,Wagon, Box, Delivery van & 59.856 .449 .936 & 64.330 .790 .521 & 82.514 .305 .736 & 99.417 .793 .949 & 100.780 .819 .210 \\
\hline Dum truck, truck tangki dan sejenisnya & 12.075 .339 .550 & 11.755 .522 .600 & 11.274 .678 .725 & 14.473 .157 .900 & 16.385 .188 .200 \\
\hline Otoplet/opelet, microlet & 382.718 .300 & 393.270 .300 & 512.550 .700 & 522.762 .600 & 684.852 .700 \\
\hline Kendaraan bermotor roda tiga & 93.414 .300 & 90.479 .600 & 134.264 .000 & 234.908 .750 & 333.736 .900 \\
\hline Sepeda motor & 118.423 .499 .400 & 115.323 .236 .050 & 122.289 .200 .100 & 143.890 .435 .900 & 173.414 .825 .910 \\
\hline Alat-alat berat & 13.787 .227 .700 & 15.609 .314 .200 & 15.294 .462 .325 & 17.849 .995 .900 & 24.367 .948 .300 \\
\hline \multicolumn{1}{|c|}{ Total } & $\mathbf{7 9 5 . 8 7 6 . 2 5 5 . 0 8 6}$ & $\mathbf{8 4 3 . 7 5 6 . 8 4 9 . 8 9 5}$ & $\mathbf{1 . 0 4 6 . 2 5 1 . 2 8 3 . 5 1 2}$ & $\mathbf{1 . 2 9 2 . 6 7 5 . 5 5 4 . 4 7 0}$ & $\mathbf{1 . 5 8 6 . 4 9 1 . 8 6 1 . 5 7 8}$ \\
\hline
\end{tabular}

Sumber : Badan Pelayanan Pajak dan Retribusi Daerah Provinsi DKI Jakarta

\section{Hasil dan Pembahasan}

Pengolahan data dalam penelitian ini menggunakan program Microsoft Excel dan Software SPSS versi 22 dan data yang diolah adalah Pengaruh Kesadaran Wajib Pajak dan Sistem Samsat Drive Thru Terhadap Kepatuhan Wajib Pajak di Kantor Samsat Jakarta Barat.

\section{Karakteristik Responden}

Terdapat lima karakteristik responden yang dimasukkan dalam penelitian ini, yaitu jenis kelamin, status responden, usia responden, tingkat pendidikan, dan lama menjadi Wajib Pajak. Karakteristik responden tersebut akan djelaskan lebih lanjut pada tabel mengenai data responden sebagai berikut:

Tabel 6. Karakteristik Responden

\begin{tabular}{|c|c|c|c|}
\hline \multicolumn{4}{|c|}{ Karakteristik Responden Berdasarkan Jenis Kelamin } \\
\hline No & Jenis Kelamin & Jumlah & Persentase \\
\hline 1 & Laki-laki & 64 & $64 \%$ \\
\hline 2 & Perempuan & 36 & $36 \%$ \\
\hline \multicolumn{2}{|r|}{ Total } & 100 & $100 \%$ \\
\hline \multicolumn{4}{|c|}{ Karakteristik Responden Berdasarkan Status Pernikahan } \\
\hline No & Status & Jumlah & Persentase \\
\hline 1 & Belum menikah & 67 & $67 \%$ \\
\hline 2 & menikah & 33 & $33 \%$ \\
\hline \multicolumn{2}{|r|}{ Total } & 100 & $100 \%$ \\
\hline
\end{tabular}


Jurnal Akuntansi \& Perpajakan, Volume 1, No. 2, Januari 2020

\begin{tabular}{|c|c|c|c|}
\hline No & Usia Responden & Jumlah & Persentase \\
\hline 1 & $20-30$ tahun & 49 & $49 \%$ \\
\hline 2 & 31-40 tahun & 28 & $28 \%$ \\
\hline 3 & 41-50 tahun & 20 & $20 \%$ \\
\hline 4 & $>50$ tahun & 3 & $3 \%$ \\
\hline \multicolumn{2}{|r|}{ Total } & 100 & $100 \%$ \\
\hline \multicolumn{4}{|c|}{ Karakteristik Responden Berdasarkan Tingkat Pendidikan } \\
\hline No & Tingkat Pendidikan & Jumlah & Persentase \\
\hline 1 & SMA/Sederajat & 85 & $85 \%$ \\
\hline 2 & D3 & 8 & $8 \%$ \\
\hline 3 & S1 & 6 & $5 \%$ \\
\hline 4 & Lainnya & 1 & $1 \%$ \\
\hline \multicolumn{2}{|r|}{ Total } & 100 & $100 \%$ \\
\hline \multicolumn{4}{|c|}{ Karakteristik Responden Berdasarkan Lama Menjadi WP } \\
\hline No & Lama Menjadi WP & Jumlah & Persentase \\
\hline 1 & $1-5$ tahun & 51 & $51 \%$ \\
\hline 2 & 6-10 tahun & 36 & $36 \%$ \\
\hline 3 & 11-15 tahun & 8 & $8 \%$ \\
\hline 4 & $>15$ tahun & 5 & $5 \%$ \\
\hline \multicolumn{2}{|c|}{ Total } & 100 & $100 \%$ \\
\hline
\end{tabular}

Sumber : Data primer yang diolah (2018)

\section{Hasil Uji dan Analisis}

\section{Analisis Deskriptif Variabel}

Deskripsi variabel dari 100 responden dalam penelitian dapat dilihat pada tabel berikut:

Tabel 7. Statistik Deskriptif Variabel

\begin{tabular}{|l|r|r|r|r|r|}
\hline & N & Minimum & Maximum & Mean & Std. Devation \\
\hline Kesadaran Wajib Pajak & 100 & 18 & 30 & 25,1 & 2,928 \\
Sistem Samsat Drive Thru & 100 & 20 & 35 & 29,11 & 2,988 \\
Kepatuhan Wajib Pajak & 100 & 29 & 50 & 40,74 & 4,489 \\
Valid N & 100 & & & & \\
\hline
\end{tabular}

Sumber : Output SPSS 22 (2018)

Kesadarann Wajib Pajak menunjukkan nilai minimum sebesar 18 dan nilai maximum sebesar 30. Mean tabel 7 menunjukkan statistik deskriptif dari masing-masing variabel penelitian. Berdasarkan tabel hasil analisis dengan menggunakan statistik deskriptif terhadap variabel kesadaran (ratarata) sebesar 25,1 dengan standar deviasi sebesar 2,928. Kemudian hasil analisis dengan menggunakan statistik deskriptif terhadap variabel sistem samsat Drive Thru menunjukkan nilai minimum sebesar 20 
Jurnal Akuntansi \& Perpajakan, Volume 1, No. 2, Januari 2020

maximum 35 mean (rata-rata) 29,11 dan 50 mean (rata-rata) sebesar 29 maximum 50 dengan standar deviasi sebesar 2,988. mean (rata-rata) 40,74 dengan standar Sedangkan variabel Kepatuhan Wajib Pajak deviation 4,489.

menunjukkan nilai minimum 29 maximum

Uji Validitas

Validitas adalah keadaan yang bersangkutan mampu mengukur apa yang menggambarkan tingkat instrumen yang akan diukur. (Sugiyono, 2016 : 121).

Tabel 8. Uji Validitas

\begin{tabular}{|c|c|c|c|c|}
\hline Variabel & Item & $\begin{array}{c}\mathbf{R} \\
\text { Hitung }\end{array}$ & $\begin{array}{c}\mathbf{R} \\
\text { tabel }\end{array}$ & Keterangan \\
\hline \multirow{6}{*}{$\begin{array}{c}\text { Kesadaran Wajib } \\
\text { Pajak }\end{array}$} & Q1 & 0,779 & 0,195 & Valid \\
\hline & $\mathrm{Q} 2$ & 0,783 & 0,195 & Valid \\
\hline & Q3 & 0,765 & 0,195 & Valid \\
\hline & $\mathrm{Q} 4$ & 0,609 & 0,195 & Valid \\
\hline & Q5 & 0,636 & 0,195 & Valid \\
\hline & Q6 & 0,433 & 0,195 & Valid \\
\hline \multirow{7}{*}{$\begin{array}{c}\text { Sistem Samsat Drive } \\
\text { Thru }\end{array}$} & Q7 & 0,314 & 0,195 & Valid \\
\hline & Q8 & 0,603 & 0,195 & Valid \\
\hline & Q9 & 0,815 & 0,195 & Valid \\
\hline & Q10 & 0,681 & 0,195 & Valid \\
\hline & Q11 & 0,740 & 0,195 & Valid \\
\hline & Q12 & 0,595 & 0,195 & Valid \\
\hline & Q13 & 0,815 & 0,195 & Valid \\
\hline \multirow{10}{*}{$\begin{array}{c}\text { Kepatuhan Wajib } \\
\text { Pajak }\end{array}$} & Q14 & 0,669 & 0,195 & Valid \\
\hline & Q15 & 0,684 & 0,195 & Valid \\
\hline & Q16 & 0,576 & 0,195 & Valid \\
\hline & Q17 & 0,522 & 0,195 & Valid \\
\hline & Q18 & 0,737 & 0,195 & Valid \\
\hline & Q19 & 0,786 & 0,195 & Valid \\
\hline & Q20 & 0,739 & 0,195 & Valid \\
\hline & Q21 & 0,465 & 0,195 & Valid \\
\hline & $\mathrm{Q} 22$ & 0,685 & 0,195 & Valid \\
\hline & Q23 & 0,585 & 0,195 & Valid \\
\hline
\end{tabular}

Sumber : Data primer yang diolah (2018)

\section{Ujia Realibilitas}

Uji reliabilitas berguna untuk menetapkan apakah instrument yang dalam kuesioner dapat digunakan lebih dari satu kali, paling tidak pada responden yang sama. Alat untuk mengukur reliabilitas adalah 
Jurnal Akuntansi \& Perpajakan, Volume 1, No. 2, Januari 2020

Koefisien Alpha Cronbach. Apabila dinyatakan bahwa instrumen kuisioner koefisien alpha >0,6 maka dapat yang digunakan adalah reliabel.

Tabel 9. Uji Realibilitas

\begin{tabular}{|c|l|c|l|}
\hline No & \multicolumn{1}{|c|}{ Variabel } & Cronbach' Alpha $^{\prime}$ & Keterangan \\
\hline 1. & Kesadaran Wajib Pajak & 0,768 & Reliabel \\
\hline 2. & $\begin{array}{l}\text { Sistem Samsat Drive } \\
\text { Thru }\end{array}$ & 0,759 & Reliabel \\
\hline 3. & Kepatuhan Wajib Pajak & 0,761 & Reliabel \\
\hline
\end{tabular}

Sumber : Data primer yang diolah (2018)

\section{Hasil Uji Asumsi Klasik}

Uji normalitas dilakukan untuk menguji nilai variabel pengganggu terdistribusi normal atau mendekati normal dengan statistik Kolgomorov-Smirnov. Hasil test menunjukkan bahwa berdasarkan nilai sig (2-tailed) $>$ dari lefel of significant $(0,05)$.

Tabel 10. Uji Normalitas

One-Sample Kolmogorov-Smirnov Test

\begin{tabular}{|ll|r|}
\hline & & LNRES \\
\hline $\mathrm{N}$ & & 61 \\
Normal Parameters ${ }^{\mathrm{a}, \mathrm{b}}$ & Mean &, 4089 \\
& Std. &, 81755 \\
& Deviation &, 098 \\
Most Extreme & Absolute &, 074 \\
Differences & Positive &,- 098 \\
& Negative &, 098 \\
Test Statistic & &, $200^{\mathrm{c}, \mathrm{d}}$ \\
Asymp. Sig. (2-tailed) & & \\
\hline
\end{tabular}
a. Test distribution is Normal.
b. Calculated from data.
c. Lilliefors Significance Correction.
$\mathrm{d}$. This is a lower bound of the true significance.

Sumber : Output SPSS $22(2018$

Uji Multikolinieritas

Uji multikolinieritas manunjukkan bahwa semua nilai tolerance lebih besar dari nilai 
Jurnal Akuntansi \& Perpajakan, Volume 1, No. 2, Januari 2020

default yang ditentukan sebesar 0,10 . Sedangkan untuk nilai VIF juga menunjukkan di bawah angka 10 . Sehingga dapat disimpulkan bahwa semua variabel telah memenuhi persyaratan ambang toleransi dan nilai VIF, artinya bahwa tidak terjadi problem multikolinieritas.

Tabel 11. Uji Multikolinieritas

Dependent Variable: KEPATUHAN

\begin{tabular}{|ll|r|r|}
\hline \multirow{2}{*}{ Model } & \multicolumn{3}{|c|}{ Collinearity Statistics } \\
\cline { 3 - 4 } & (Constant) & & \\
& & & \\
& KESADARAN &, 922 & 1,085 \\
& DRIVE THRU &, 922 & 1,085 \\
& & & \\
& & &
\end{tabular}

Sumber : Output SPSS 22 (2018)

\section{Hasil Uji Regresi Berganda}

Pengujian hipotesis $\mathrm{H}_{1}$ dan $\mathrm{H}_{2}$ dilakukan dengan analisis regresi berganda pengaruh kesadaran Wajib Pajak dan sistem samsat
Drive Thru terhadap keasadaran Wajib Pajak. Hasil pengujian tersebut ditampilkan sebagai berikut :

Tabel 12. Uji F- Uji Simultan

\begin{tabular}{|rl|r|r|r|r|r|}
\hline \multicolumn{2}{|c|}{ ANOVA $^{\text {a }}$} \\
\hline Model & \multicolumn{1}{|c|}{$\begin{array}{c}\text { Sum of } \\
\text { Squares }\end{array}$} & Df & Mean Square & F & Sig. \\
\hline & Regression & 941,020 & 2 & 470,510 & 43,292 &, $000^{\mathrm{b}}$ \\
& Residual & 1054,220 & 97 & 10,868 & & \\
& Total & 1995,240 & 99 & & & \\
\hline
\end{tabular}

a. Dependent Variable: KEPATUHAN WAJIB PAJAK

b. Predictors: (Constant), SISTEM SAMSAT DRIVE THRU, KESADARAN WAJIB PAJAK

Sumber : Output SPSS 22 (2018)

Berdasarkan tabel 12 dapat dilihat bahwa dalam pengujian regresi berganda menunjukkan hasil $\mathrm{F}$ hitung sebesar 43,292 dengan tingkat signifikansi 0,000. Tingkat signifikansi lebih kecil jika dibandingkan 0,05 maka model regresi dapat digunakan untuk memprediksi Y atau dapat dikatakan bahwa variabel independen secara bersama-sama berpengaruh secara signifikan terhadap Y. 
Jurnal Akuntansi \& Perpajakan, Volume 1, No. 2, Januari 2020

Berarti variabel kesadaran Wajib Pajak bersama-sama berpengaruh terhadap dan sistem Samsat Drive Thru secara kepatuhan Wajib Pajak.

Tabel 13. Uji T- Uji Parsial

Coefficients $^{\mathrm{a}}$

\begin{tabular}{|c|c|c|c|c|c|c|}
\hline \multirow{2}{*}{\multicolumn{2}{|c|}{ Model }} & \multicolumn{2}{|c|}{$\begin{array}{l}\text { Unstandardized } \\
\text { Coefficients }\end{array}$} & \multirow{2}{*}{$\begin{array}{c}\text { Standardized } \\
\text { Coefficients }\end{array}$} & \multirow[b]{2}{*}{$\mathrm{t}$} & \multirow[b]{2}{*}{ Sig. } \\
\hline & & B & Std. Error & & & \\
\hline \multirow[t]{3}{*}{1} & (Constant) & 6,017 & 3,822 & & 1,575 & ,119 \\
\hline & $\begin{array}{l}\text { KESADARAN WAJIB } \\
\text { PAJAK }\end{array}$ &, 754 & ,118 & ,492 & 6,401 & ,000 \\
\hline & $\begin{array}{l}\text { SISTEM SAMSAT } \\
\text { DRIVE THRU }\end{array}$ &, 542 & ,115 & ,361 & 4,697 &, 000 \\
\hline
\end{tabular}

a. Dependent Variable: KEPATUHAN WAJIB PAJAK

Sumber : Output SPSS 22 (2018)

Berdasarkan tabel 4.15. di atas dapat dianalisis model estimasi sebagai berikut:

$\mathrm{Y}=6.017+0,754 \mathrm{X}_{1}+0,542 \mathrm{X}_{2}+\mathrm{e}$

Keterangan :

$\mathrm{Y} \quad=$ Kepatuhan Wajib Pajak

a $\quad=$ kostanta

$\mathrm{X}_{1} \quad=$ Kesadaran Wajib Pajak

$\mathrm{X}_{2} \quad=$ Sistem Samsat Drive Thru

e $\quad=$ Error Term, yaitu tingkat kesalahan penduga dalam penelitian.

Hasil interpretasi atas hipotesis penelitian $\left(\mathrm{H}_{1}\right.$ dan $\left.\mathrm{H}_{2}\right)$ yang merupakan variabel independen berpengaruh terhadap variabel dependen dapat dijelaskan sebagai berikut:

a. Kesadaran Wajib Pajak berpengaruh positif dan signifikan terhadap kepatuhan Wajib Pajak $\left(\mathrm{H}_{1}\right)$.

$\mathrm{H}_{\mathrm{o}}: \mathrm{b}_{2}=0$ : Kesadaran Wajib Pajak tidak berpengaruh positif signifikan terhadap kepatuhan Wajib Pajak.

$\mathrm{H}_{\mathrm{o}}: \mathrm{b}_{2}>0$ : Kesadaran Wajib Pajak berpengaruh positif signifikan terhadap kepatuhan Wajib Pajak.
Berdasarkan tabel 13 dapat dilihat hasil pengujian hipotesis dengan SPSS diperoleh untuk variabel $\mathrm{X}_{1}$ yaitu, kesadaran Wajib Pajak diperoleh nilai hitung sebesar 6.401 dengan tingkat signifikansi $\quad 0,000$. Dengan menggunakan batas signifikan 0,05 nilai signifikansi tersebut lebih kecil dari taraf 5\% yang berarti $\mathrm{H}_{\mathrm{o}}$ ditolak dan $\mathrm{H}_{\mathrm{a}}$ diterima. Dengan demikian maka hipotesis pertama diterima.

b. Sistem Samsat Dive Thru berpengaruh positf dan signifikan terhadap kepatuhan Wajib Pajak $\left(\mathrm{H}_{2}\right)$. 
Jurnal Akuntansi \& Perpajakan, Volume 1, No. 2, Januari 2020

$\mathrm{H}_{\mathrm{o}}: \mathrm{b}_{2}=0:$ Sistem Samsat Drive Thru

tidak berpengaruh positif signifikan terhadap kepatuhan Wajib Pajak.

$\mathrm{H}_{\mathrm{o}}: \mathrm{b}_{2}>0$ : Sistem Samsat Drive Thru berpengaruh positif signifikan terhadap kepatuhan Wajib Pajak.

Berdasarkan tabel 13 dapat dilihat hasil pengujian hipotesis dengan SPSS diperoleh variabel $\mathrm{X}_{2}$ yaitu sistem Samsat Drive Thru dengan nilai hitung sebesar 4.697 tingkat signifikansi 0,000 . Dengan menggunakan batas signifikan 0,05 nilai signifikansi tersebut lebih kecil dari taraf 5\% yang berarti $\mathrm{H}_{0}$ ditolak dan $\mathrm{H}_{\mathrm{a}}$ diterima. Dengan demikian maka hipotesis kedua diterima.

\section{Tabel 14. Hasil Uji Koefisien Determinasi}

\begin{tabular}{|c|c|c|c|c|}
\hline \multicolumn{5}{|c|}{ Model Summary ${ }^{b}$} \\
\hline Model & $\mathrm{R}$ & $\begin{array}{c}\mathrm{R} \\
\text { Square }\end{array}$ & $\begin{array}{c}\text { Adjuste } \\
\text { d R } \\
\text { Square }\end{array}$ & Std. Error of the Estimate \\
\hline 1 &, $687^{\mathrm{a}}$ & ,472 & ,461 & 3,29670 \\
\hline
\end{tabular}

a. Predictors: (Constant), SISTEM SAMSAT DRIVE THRU, KESADARAN WAJIB PAJAK

Berdasarkan hasil uji koefisien determinasi pada tabel 14 , nilai $\mathrm{R}^{2}$ ( $\mathrm{R}$ square) dari model regresi digunakan untuk mengetahui seberapa besar kemampuan variabel bebas (indepent) dalam menerangkan variabel terikat (dependent). Dari tabel 14

\section{KESIMPULAN}

Berdasarkan hasil analisis menunjukkan bahwa kesadaran Wajib Pajak berpengaruh positif terhadap kepatuhan Wajib Pajak. Hal ini berarti bahwa semakin tinggi kesadaran wajib Pajak maka semakin tinggi kepatuhan Wajib Pajak. Demikian juga hasil analisis sistem Samsat Drive Thru berpengaruh positif terhadap kepatuhan Wajib Pajak. Hal ini menunjukkan bahwa semakin berkualitas sistem Samsat Drive Thru, maka semakin meningkatkan menunjukkan bahwa nilai $\mathrm{R}^{2}$ ( $\mathrm{R}$ square) sebesar 0,472, hal ini berarti bahwa 47,2\% yang menunjukkan bahwa kepatuhan Wajib Pajak dipengaruhi oleh variabel kesadaran Wajib Pajak dan sistem Samsat Drive Thru.

kepatuhan Wajib Pajak yang berdampak terhadap penerimaan dari sektor pajak kendaraan bermotor

Saran: Berdasarkan hasil penelitian maka penulis memberikan saran yaitu: Kantor Samsat, diharapkan untuk meningkatkan pelayanan dengan melakukan sosialisasi dan tata cara pembayaran pajak kepada masyarakat serta memberikan informasi yang lengkaap terhadap inovasi-inovasi yang akan disiapkan. 
Jurnal Akuntansi \& Perpajakan, Volume 1, No. 2, Januari 2020

\section{DAFTAR PUSTAKA}

Bahari, Firsada., Siti Rochmah., Stefanus Pani Rengu., 2012, Penerapan Sistem Administrasi Manunggal Satu Atap (SAMSAT) Drive Thru Dalam

Meningkatkan Pelayanan Publik

(Studi pada Kantor Bersama Samsat

Kabupaten Lamongan, Jurnal

Administrasi Publik (JAP) vol. 1 No. 4: 48-57..

Ilhamsyah, Randi, Maria G Wi Endang., Rizky Yudhi Dewantara., 2016, Pengaruh Pemahaman dan Pengetahuan Wajib Pajak Tentang Peraturan Perpajakan, Kesadaran Wajib Pajak, Kualitas Pelayanan, dan Sanksi Perpajakan Terhadap Kepatuhan Wajib Pajak Kendaraan Bermotor (Studi Samsat Kota Malang), Jurnal Perpajakan (JEJAK) vol. 8 No.1: 1-9.

Lasmana, J. Eko., 2017, Undang-Undang Pajak Lengkap, Jakarta : Mitra Wacana Media.

Nugroho, Samekto Adi., 2017, FaktorFaktor Penghambat Pelayanan Berbasis E-Government Pada Pembayaran Pajak Kendaraan Bermotor Dengan Sistem Anjungan Transaksi Mesin Kantor Bersama Samsat Di Surabaya Timur), Jurnal Kebijakan dan Manajemen Publik vol. 5 No. 2: 1-8.

Sinambela, Tongam,. 2016, Perpajakan Edisi 1, Yogyakarta: Deepbulish.

Sinambela, Lijan Poltak., 2014, Metodologi Penelitian Kuantitatif., Untuk bidang Ilmu Administrasi, Kebijakan Publik, Ekonomi, Sosiologi, Komunikasi dan Ilmu Sosial Lainnya, Yogyakarta: Graha Ilmu.
Soebechi, Imam., 2011, Judicial Review Perda Pajak dan Retribusi Daerah, Jakarta:Sinar Grafika.

Solicha, Evi Kurniatus., Topowijono., Sri Sulasmiyati., 2015, Tingkat Kepatuhan Wajib Pajak Ditinjau Dari Penerapan Tiga Layanan Unggulan Samsat Jawa Timur (Studi Pada Wajib Pajak Kendaraan Bermotor Kantor Bersama Samsat Malang Kota-UPT DIPENDA Jatim Malang Kota), Jurnal Administrasi-Perpajakan (JAB) v0l. 5 No. 2: 1-9

Sugiyono., 2016, Metode Penelitian Kuantitatif, Kualitatif, dan $R \& D$, Bandung: Alfabeta.

Ulum, Bahrul., 2015, Kualitas Pelayanan Electronic Samsat Pada Kantor Siistem Manunggal Satu Atap (Samsat) Manyar Kertoarjo Surabaya Timur, Jurnal Publika Universitas Negeri Surabaya Vol. 01 No. 01: 1-12. Wardani, Dewi Kusuma dan Rumiyatun., 2017, Pengaruh Pengetahuan Wajib Pajak, Kesadaran Wajib Pajak, Sanksi Pajak Kendaraan Bermotor, dan Sistem Samsat Drive Thru Terhadap Kepatuhan Wajib Pajak Kendaraan Bermotor

E-jurnal Akuntansi Universitas Sarjanawiyata Taman Siswa Yogyakarta Vol. 5 No.1: 15-23.

Yulianawati, Nila., 2011, Faktor-faktor yang Mempengaruhi Kemauan Membayar Pajak, E-jurnal Dinamika Keuangan dan Perbankan Universitas Stikubank vol. 3 No.1: 126-142.

Anonim. http://www.bprd.jakarta.go.id (Diakses pada 19 April 2018).

Anonim. http://www.data.jakarta.go.id (Diakses pada 19 April 2018). 